\title{
National transport policy in Austria - from its beginning till today
}

\author{
Guenter Emberger $^{1}$ (D)
}

Received: 7 October 2016 / Accepted: 4 January 2017 / Published online: 24 January 2017

(C) The Author(s) 2017. This article is published with open access at SpringerLink.com

\begin{abstract}
Introduction The objective of the paper is to research the historic development of the Austrian transport policy. It explores when a transport strategy was made for the first time, from whom, and which purpose was pursuit. It shows how the objectives of the transport strategy changed over time and when passenger and freight transport took over to become the main focus of the planning process. Furthermore it is researched when, and if, there was a change from a solely sectorial mono-modal transport strategy (road, rail separated) towards an integrated transport planning process and when, and if, there was a development away from a demand-fulfillment-driven transport planning paradigm towards a transport-demandmanagement driven transport planning strategy.

Methods The information used stemmed from an analysis of existing transport master plans and other political documents and reports published in Austria within the last decades. In a subsequent step the results of this analysis are assessed against the so called "Ideal Decision Making Process" (IDMP) developed in former research activities, and shows in a clear way how the transport strategy in Austria evolved and improved over time.

Results Comprehensive overview of the development of Austria's transport strategy over time including all means of transport.
\end{abstract}

This article is part of Topical Collection on The development of National Transport Policy

Guenter Emberger

Guenter.Emberger@tuwien.ac.at

1 Vienna University of Technology, Gusshausstrasse 30/2, Vienna 1040, Austria
Conclusion The Austrian transport strategy evolved over the last 40 years from a sectorial, demand-fulfillment-driven transport strategy towards an integrated multi-modal, demand-management-driven transport strategy including some environmental issues. Further, an outlook is provided in which direction the national transport planning strategies should be developed to be able to tackle future challenges such economic, social and ecologic sustainability.

Keywords National transport Policy $\cdot$ Historical development, Austria $\cdot$ Transport planning $\cdot$ National transport master plan

\section{Introduction}

All countries in Europe and elsewhere in the world struggle with similar problems regarding transport: Congestion and time losses, too few infrastructure, growing demand for mobility, growing demand in freight transport, shortcomings in financing of new transport infrastructures, backlog in the maintenance of the existing infrastructure, environmental and safety issues, to name only a few of them. Most of the countries try to tackle these issues by preparing national transport master plans to address the above-mentioned challenges and to mitigate negative impacts of transportation on society and environment.

In this paper, the main focus is to analyze how Austria has tackled these issues in the last century, which political processes are in place and how successful Austria was/is in the field of preparing strategic national transport master plans (TMPs).

The paper is structured in the following way: In section 2 background information about Austria is given. In addition, a short history regarding the rail and road system development in Austria is provided. In Section 3 an overview of the 
government constellations in Austria since 1945 is provided and their governmental declarations regarding transport policy are summarised. Furthermore, a full list of existing documents officially published which describe the Austrian national transport policy (= national transport master plans (TMP)) are listed and commented by the author.

In Section 4, previous research regarding the identification of an optimal decision-making process is introduced and in the subsequent section an assessment of the Austrian TMPs activities against this ideal decision making process is carried out. In the final section, conclusions are drawn and further research needs are proposed.

\section{Background information about Austria}

Austria is a small country (about $84.000 \mathrm{~km}^{2}$ ) in the heart of Europe. In Austria there are 8.4 million inhabitants (year 2015), and the national language is German. Austria has borders with eight countries (Germany, Czech Republic, Slovakia, Hungary, Slovenia, Italy, Switzerland and Liechtenstein). In five of them a different language (= not German) is spoken. Before 1989, Austria was located on the western side of the Iron Curtain; since then the borders are open and free travel to all neighboring countries is possible. At present Austria is number 11 in the world ranking regarding GDP per capita.

In the following figures the development of some key indicators for Austria is given:

Figure 1 depicts the development of population in Austria and the development of the number of cars on Austrian roads. As it can be seen, there took place a moderate increase in population, while the number of cars exploded from 1950 onwards. Nowadays there are in total more than 4 million cars on the roads in Austria.

Figure 2 shows the economic development in Austria from 1900 onwards. It can be seen there was a steady growth in the GDP per capita from 1950 (after WWII) onwards.

Figure 3 shows the development of the car motorisation rate in Austria, ${ }^{1}$ presently there are more than 500 cars per 1000 inhabitants in Austria. There is a tendency that the growth of the motorisation rate is slowing-down in the last decade, but it is not foreseeable at the moment at which level the motorisation rate will peak.

Figure 4 shows the development of the indicators GDP per capita and the development of the Austrian population in relative terms. Base year is the year 1950. As it can be seen, the GDP grows compared to the year 1950 by 6.5 times until today, whereas the population has been more or less stable

\footnotetext{
${ }^{1}$ The disruption of the trend line in year 2002/2003 is due to a change in the statistical method used (adaption of vehicle counting following regulation ("Verordnung") BGB1. II Nr. 193/2002).
}

in the same period. These developments are comparable to developments which took place in other European countries (Germany, Italy, France, UK, etc.).

Figure 5 shows the development of specific transport infrastructures in the UK supplemented with the motorway network development in Austria in percent of the total network lengths in kilometer. The first three curves depict the infrastructure development in the UK. Construction of canals started around 1790 and was finished around 1850. Then railway construction started in the early 19th century and was finished around 1940 [3; p. 112]. The curve for the rail network of Austria is similar to the curve of the UK rail network, but a little bit later (about 10 to 15 years).

Then construction of the road network in the UK started in 1870 and was almost finished in 1990 . Of course there existed roads before the year 1870; in this investigation only road construction for motorised vehicles was taken into consideration. In the present time, minor new road construction sites still exist, but the majority of the network is already finished.

A time-lagged but similar development of infrastructure construction can be found in Austria (rightmost curve in Fig. 5 - here the development of the motor- and expressway network is shown). Remarkable here is the finding by Grübler and Marchetti [1, 4] that the time lag between the different kinds of infrastructures is about 60 years. They assumed that these time lags are likely the causes for the Kondratiev ${ }^{2}$ cycles. New means of transport will potentially fill the gap, such as air transport and high speed trains.

A similar development of transport infrastructure increase took place in all European countries in the time period after WWII which fostered and enable the economic boom in the 1960ies till 1980ies in Europe. More detailed information on international/national transport infrastructure developments can be found in [5; p.111 ff.].

\subsection{History of rail way construction in Austria}

First attempts to construct horse-drawn railways in Austria started in the year 1824 to connect Budweis (today České Budějovice in Czech Republic) to the Danube.

The first rail using steam engines was Kaiser-FranzFerdinands-Nordbahn opened in 1838 , which became a very profitable system in the northern part of Austria. Since 1882, a gradual nationalisation of the railway network of the AustroHungarian Empire into the Imperial Royal Austrian State Railways (Kaiserlich-königliche österreichische Staatsbahnen, kkStB) took place.

\footnotetext{
${ }^{2}$ In economics, Kondratiev cycles are the term for a regular S-shaped cycle in the modern world economy. Fifty to sixty years in length, it consists of an alternation of periods of high sectoral growth with periods of slower growth for more info see http://en.wikipedia.org/wiki/Kondratiev_wave.
} 
Fig. 1 Development of population and car population in Austria for the period 1900 till 2015

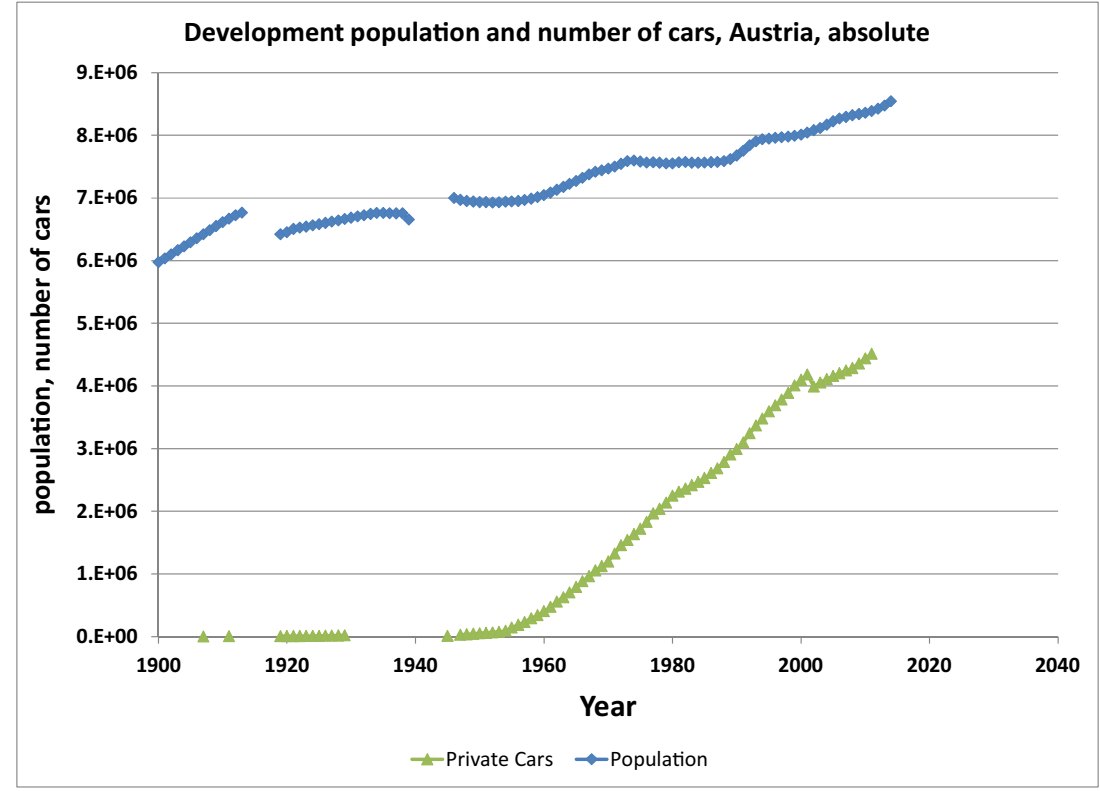

By the outbreak of the World War I (WWI), the only major railway in Austria to remain in private hands was the Austrian Southern Railway (Südbahn). After the break-up of the Austro-Hungarian Empire in the year 1918, the Austrian rump of $\mathrm{kkStB}$ remained in state control under the name Deutschösterreichische Staatsbahnen (DÖStB), which was renamed to Österreichische Staatsbahnen (ÖStB) in 1919. In the year 1923 was the foundation of the independent, commercial enterprise, the Bundesbahn Österreich. This company took over the assets of the ÖStB and the Südbahn, together with other minor railways.

In 1938 was the Anschluss of Austria into the German Empire. The BBÖ was taken over by the Deutsche Reichsbahn. During the World War II (WWII), about 41\% of the Austrian railway network was destroyed.

In 1947, the company was reformed using the slightly different name of Österreichische Bundesbahnen and the abbreviation ÖBB as a state-owned company. Their infrastructure was rebuilt and electrification was accelerated. In 1969 a new federal railway law was enacted. The ÖBB became a nonindependent, economic entity, which was run as a branch of the government's industrial programme and remained entirely within the Federal budget.

In 1992 the ÖBB were separated from the federal budget and turned into company with its own legal status. The company was $100 \%$ owned by the Republic of Austria. This change had two primary aims: first, it had to conform to EU rules on the admission of Austria into the European Union. Second, the financial demand for public funding was to be reduced as a result of improvements in efficiency and the pressure of competition.

In 2004 the ÖBB were reorganised again into ÖBB Holding $A G$ and a number of operating subsidiaries. The holding company was to oversee the operations of the companies assigned to it, coordinate a coherent strategic approach and allocate tasks for the whole enterprise. In 2005 the subsidiaries of ÖBB-Holding AG became autonomous and independent operationally. ${ }^{3}$

Electrification of the system began in year 1912 but did not reach to an advanced status until the 1950s. The last steam locomotive in regular service on the standard gauge network retired in year 1978.

According to the Annual Report 2013 [6], the company employs 39,513 people. 13,599 of them are active employees, 24,251 of them are retired employees (still on the payroll of ÖBB) and 1663 apprentices. In 2013, ÖBB-Personenverkehr AG carried 469 million passengers, of which 235 million were bus passengers. The ÖBB rail network length is $4859 \mathrm{~km}$, $72 \%$ of which is electrified. The standard gauge is $1435 \mathrm{~mm}$. The ÖBB has 1128 train stations, 1093 locomotives, 2799 passenger carriages and 26,518 freight wagons. It also operates 2200 busses: the ÖBB's bus services travel $52,500,000 \mathrm{~km}$ per year.

\subsection{History of motorway construction activities in Austria}

\subsubsection{Beginning till World War II (WWII)}

The first ideas to improve the existing road network took place in the year 1926. There was the first design study of a motorway in Austria, namely the route Vienna - Semmering. This project was eventually not

\footnotetext{
${ }^{3}$ Text based on https://de.wikipedia.org/wiki/Geschichte_der_Eisenbahn_in \% C3\%96sterreich and https://en.wikipedia.org/wiki/Austrian_Federal_ Railways
} 
Fig. 2 Development GDP per Capita in 1990 international

Geary-Khamis dollars in Austria

for the period 1900 till 2015

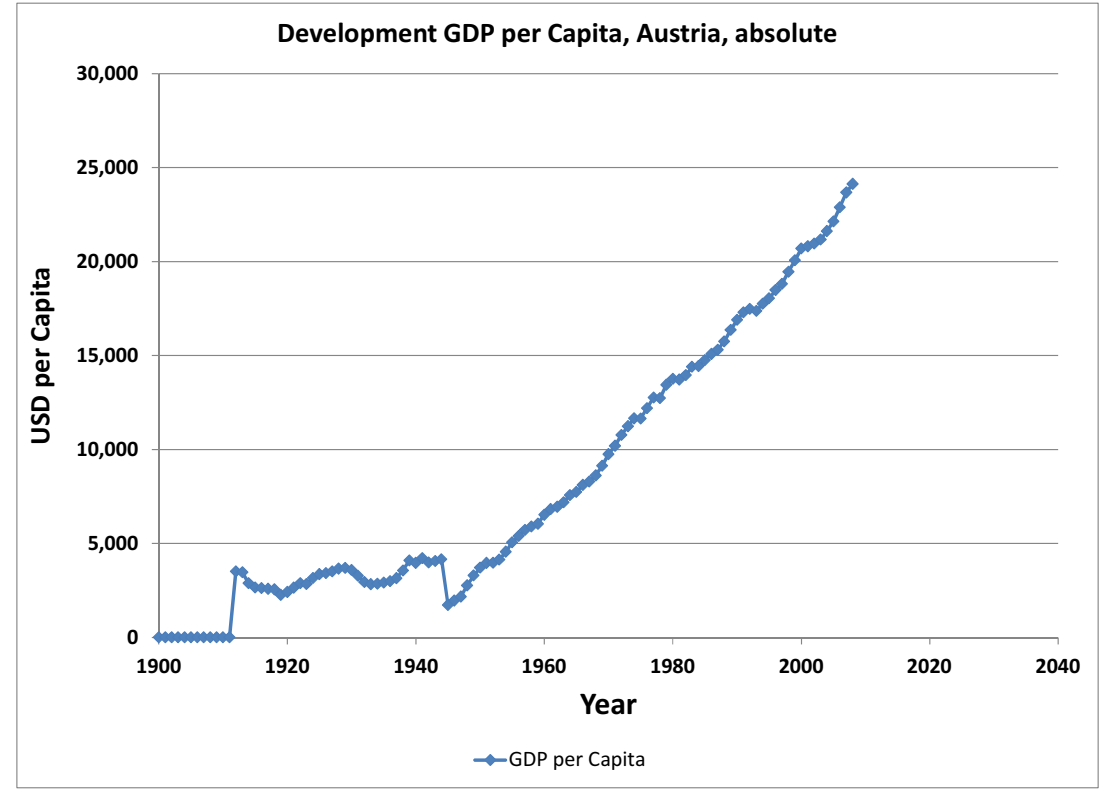

realized. In 1928 a first plan for road infrastructure development "Straßenausbaukarte" was made and in the year 1936 the first Austrian "Fernstraßennetz" plan was designed by Leopold Oerley. This plan did not include any motorways $[7 ;$ p.12].

\subsubsection{World War II (WWII)}

In March 1938 there was the "Anschluß" of Austria into Germany. In this moment Germany started simultaneously with the extension of the German "Reichsautobahn" network towards Austria. The planning principle for motorways at this time was that users should be able to "consume" the landscape while driving. Thus the shortest connection between two cities was not in the focus of the road design. The experience of the passed-by landscape was the premise for the road layout. In the very next month, namely on the 7 th of April 1938 Adolf Hitler turned the first sod for the Reichsautobahn between Salzburg and Vienna. It was planned to finalize this piece of motorway by April 1941. In reality this stretch was finally realized years later. Because of the war in the year 1942 all Reichsautobahn construction work stopped. At this time
Fig. 3 Development of motorisation rate (cars per 1000 inhabitants) in Austria for the period 1900 till 2015

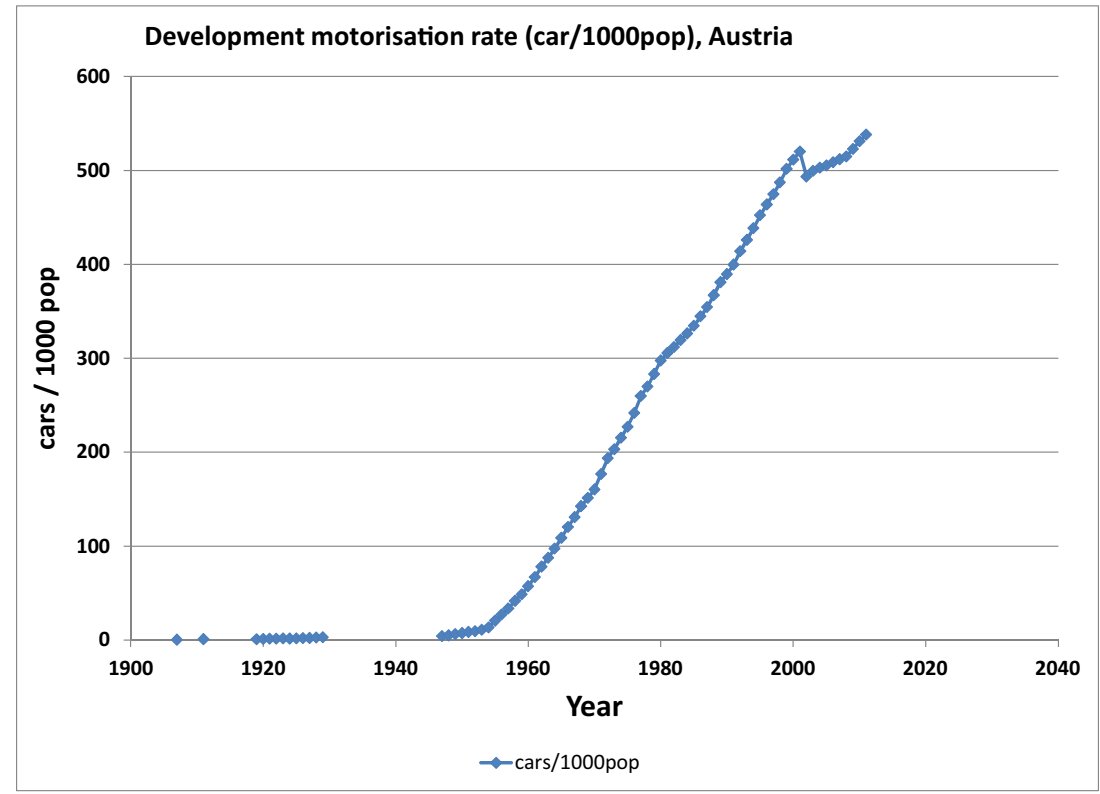


Fig. 4 Relative development of GDP per capita and population growth in Austria for the period 1900 till 2015

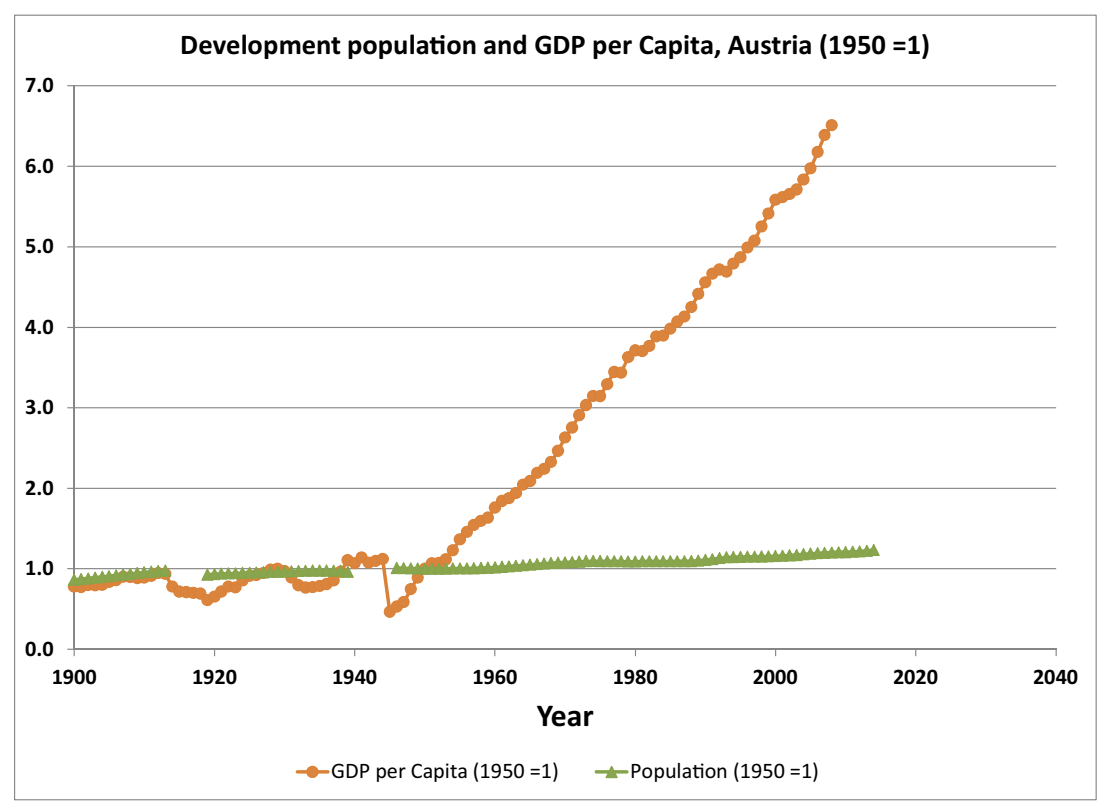

only two short motorway sections were finished with a total length of $16.8 \mathrm{~km} \mathrm{[7;} \mathrm{p.15].}$

In general it could be said that the German and Autrian "Reichsautobahnen" in the years 1937/1938 were classical supply orientated road infrastructure. This supply of motorways should have created demand for car traffic [7; p.14], but the motorization rate at this time was very low (about 3.5 cars per 1000 inhabitants) and only a few intercity traffic took place.

\subsubsection{Post World War II (WWII)}

After the WWII there was high level of unemployment in Austria as elsewhere in Europe. The Austrian government was therefore looking for possibilities to reduce it by investing in infrastructure projects. Construction work in the field of road construction was one of the opportunities to create a lot of workplaces, especially at this time, where the mechanization of road construction was in the fledgling stage. One of the first stretches to be built was the motorway between Salzburg and Vienna. In the following 30 years until the late 1970s there was a boom in motorway construction in Austria - the network was expanded from about $20 \mathrm{~km}$ in the year 1950 to more than $1000 \mathrm{~km}$ in the year 1980 (see Fig. 6).

In the period between 1980 and 2010 the motorway construction pace slowed down, with a present total length of about $2200 \mathrm{~km}$ in the year 2014. It can be said that the motorway network in Austria is finished and mature, at present there exist only some plans for some minor extensions of the motorway network (e.g. A5 extension towards Czech Republic, Lobau Tunnel near Vienna) and some extensions of additional lanes where the existing capacity of the motorways is thought to be close to their limits.
Figure 7 shows that the motorway network was expanded by more than 100 times in the last 60 years compared to the base year 1950, and the number of cars increased by more than 90 times in the same period.

Parallel to the construction and operation of the motor- and expressway network the responsibility and organization of the network responsibilities underwent several changes. After WW2 the government of Austria was the owner and in charge of the construction of the motor- and expressway network of Austria.

In 1953 the "Autobahn Studien G.m.b.H”. was founded to develop the construction program for the motorway SalzburgVienna.

1954 it was decided to close the "Autobahn Studien G.m.b.H" and the Ministry for Commerce and

\section{Development of Transport Infrastructure over time in the UK and Austria}

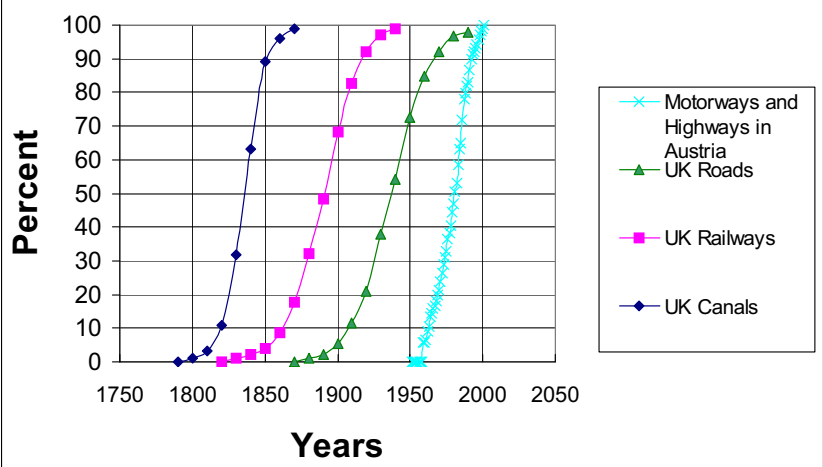

Fig. 5 Development of transport infrastructure over time in the UK and Austria, Source: [1], Statistik Straße \& Verkehr, [2], own calculations 
Fig. 6 Development of the Austrian Motorway Network for the period 1900 till 2015

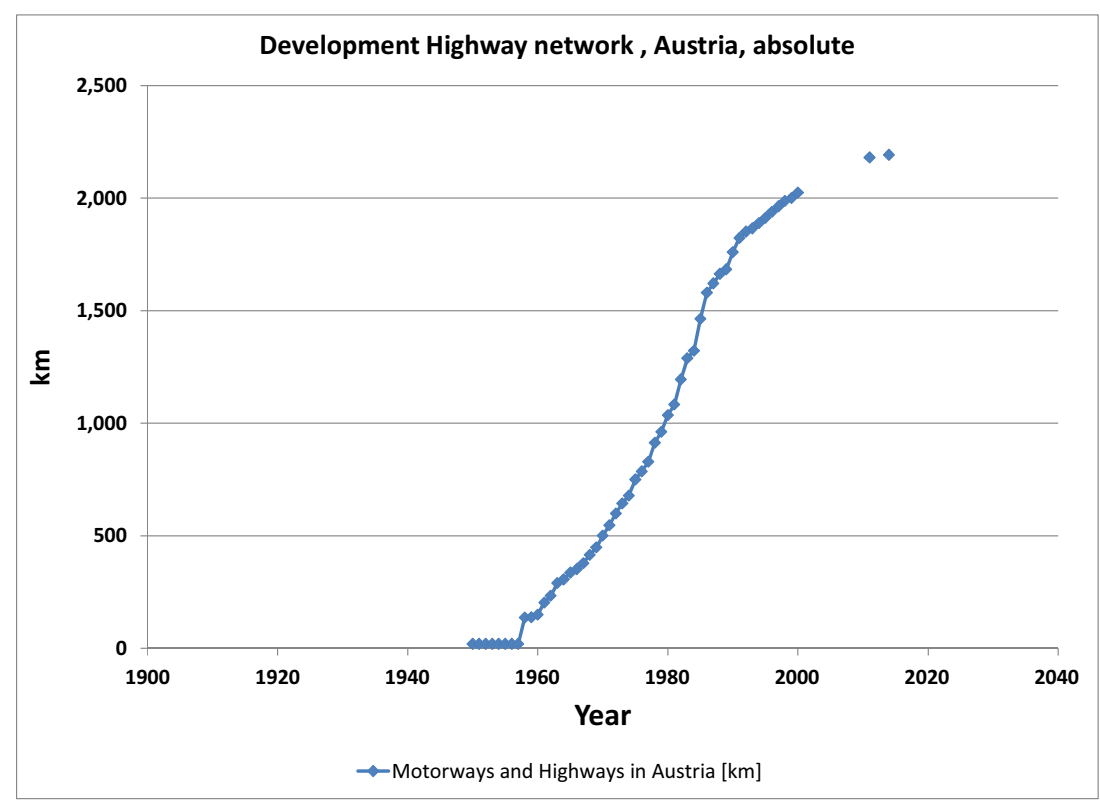

Reconstruction took over the responsibilities. In the year 1963 the Ministry for Commerce and Reconstruction enact a ministerial order where the provinces of Austria became responsible for the construction and operation of the motor- and expressway network. Based on this act a series of operational motorway companies (Bundesstraßengesellschaften) were founded, owned by the federal state of Austria and the corresponding provinces with the duty to finance and to construct the cost intensive (mostly alpine crossing) motor- and expressway routes (Brenner AutobahnAG, Tauernautobahn AG, Phyrn Autobahn AG, Arlbergstraßentunnel AG,
Autobahnen- und Schnellstraßen AG, Wiener Bundesstraßen AG, Karawanken Autobahn AG).

In 1982 the ASFINAG was founded as a central financing company. From this moment on, the credit operations were managed centrally for all motorway companies in Austria by the fully state-owned financing company ASFINAG. In 1993 the operational motorway companies in Austria were merged into two companies: Alpen Straßen AG in the west, Österreichische Autobahnen- und Schnellstraßen AG for the rest of Austria.
Fig. 7 Relative development of the motorway network and number of private cars in Austria for the period 1900 till 2015

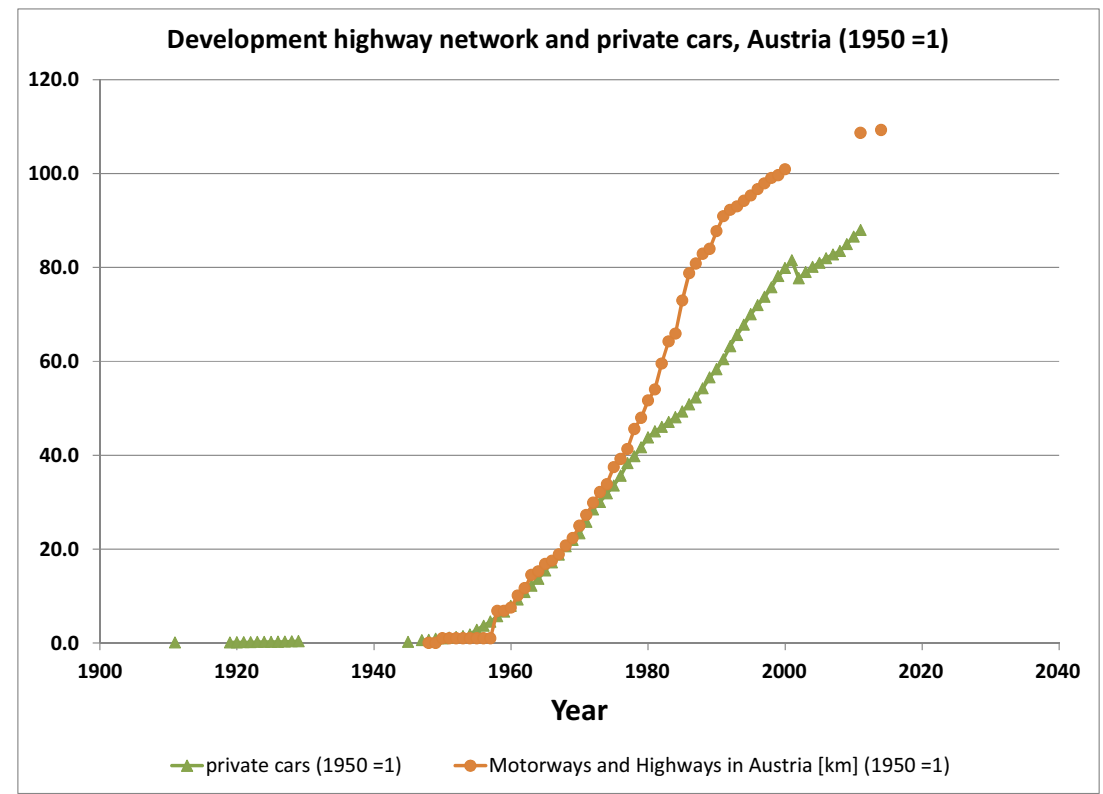


In 1997 ASFINAG assumed the overall responsibility for the network and liabilities and got the right to collect tolls and usage fees on its own behalf (right of usufruct) additionally to the revenues from the special toll routes. At this time the toll sticker (Autobahnvignette) was introduced - a time-based toll for vehicles weighing less than 12 tons maximum permissible weight. It took another 7 years to implement a HGV (heavy good vehicle) toll system, since 2004 vehicles over 3.5 tons maximum permissible weight have to pay tolls depending on the route.

In 2006 ASFINAG was reorganized in a strategic holding and three main operative companies for (1) Tolling, (2) planning and Construction and (3) Operation and Maintenance. Since that time ASFINAG is independent although state owned. It gets no taxes, ASFINAG is allowed to toll motor- and expressways but it has to pay for operation, maintenance and construction for its own.

\section{Political background - austrian transport policy}

Since the WWII Austria is a democratic country; in total there have been 28 different governments since 1945. Figure 8 provides an overview of the government constellations in Austria from 1945 until todays. In the period between 1945 and 1970 the dominating party was the
Austrian People's Party, but had to form a coalition with the Social Democratic Party until 1966. From 1967 onwards until 1970 the People's Party was in charge without the need for a coalition partner. In 1970 the responsibility switched to the Social Democratic Party until 1983, from this time onwards they had to form a coalition with the Freedom Party, which existed till 1986. In the period 1986 till 2000 a coalition between the Social Democratic Party and the Austrian People's Party under the lead of the Social Demographic Party was in place.

In 2000 there was a major change, a government coalition between the Austrian People' Party and the Freedom Party was introduced and they worked together until 2007. Since then, again Austria is governed by a coalition of the Social Democratic Party and the Austrian People's Party - this coalition is in place till today.

In Fig. 8 also an overview is provided when major transport related documents were published by the responsible ministries/ministry. At this place it has to be mentioned that until the year 2000 the responsibilities for road construction and maintenance and the responsibilities for construction and maintenance of the rail network were not located in the same ministry. Looking back it could be said that this consolidation of competences was one of the most important activities reached within the coalition between the Austrian People's Party and the Freedom Party.

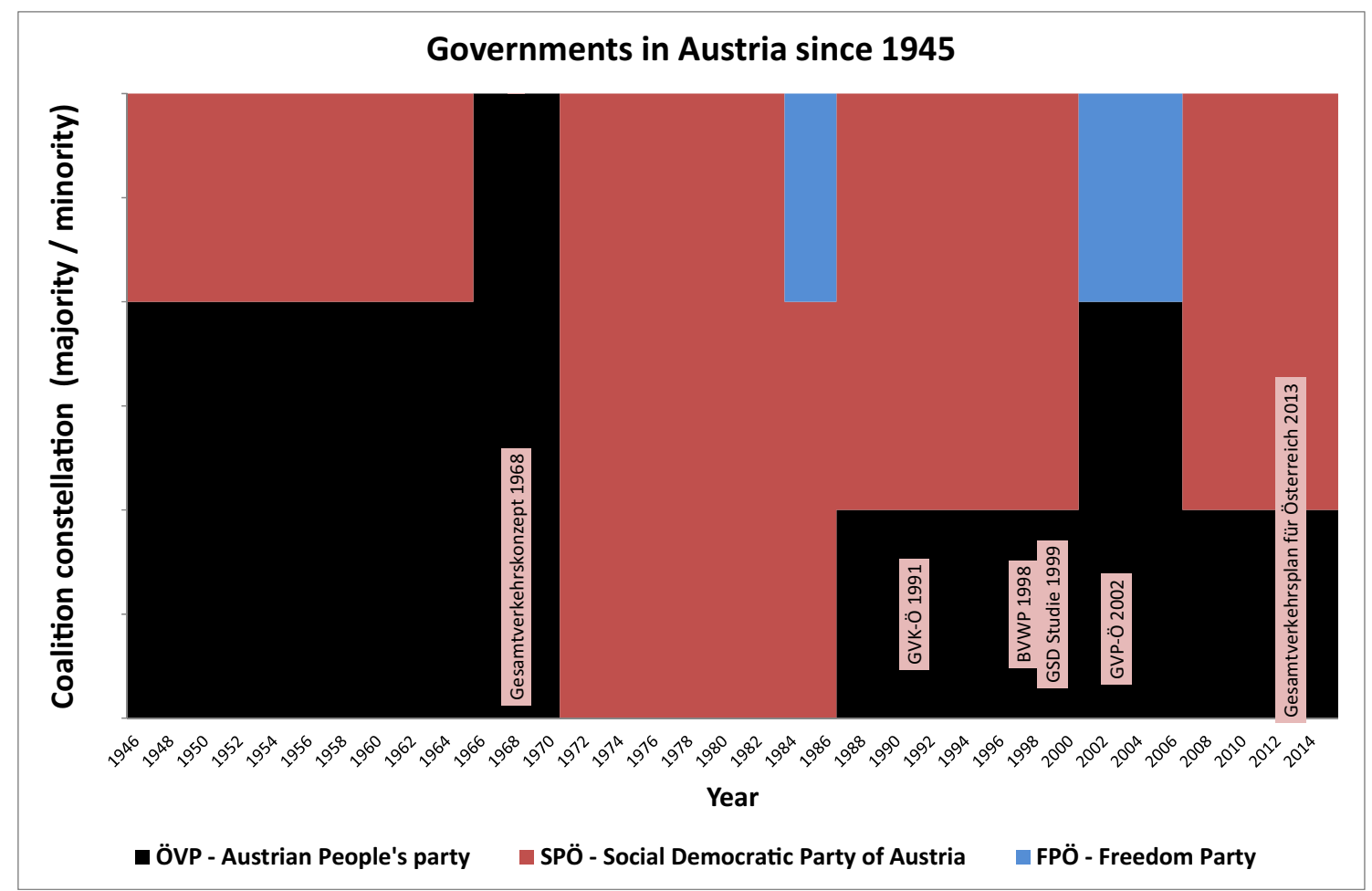

Fig. 8 Austrian governments since 1945 and transport related documents (colours in the graphic refer to the colours political parties use in Austria) 
Steiniger [8] provided a list of all Austrian government declarations since 1945 . By analysing these official published government's declarations of the 28 above mentioned governments, three different phases regarding transport policy can be identified:

\subsection{Phase 1: 1950-1970}

In the early period after WW2 road construction was mainly seen as an instrument to reduce unemployment - major road construction activities took place at this time. The road construction activities comprised some stretches of the motorway network, a second focus was put on improvements of trunk roads to enable and foster the tourism, which was growing in this period. The financing of the infrastructure improvement was easily financed from the income generated from the fuel tax paid by the car drivers. In the rail sector the electrification of the main routes of the network was on the agenda. At the end of the 1960s, the demand for fuel became higher than the inland production - to avoid a dependency on a limited number of continental oil suppliers, the government made plans to construct oil pipelines to harbours at the Mediterranean Sea to have access to world-wide oil suppliers. It was also recognised for the first time that water supply and forestry played an important role for future generations.

\subsection{Phase 2: 1970-1990}

In the year 1973/1974 Austria, as all other countries, experienced the first Oil Crisis. At this time the government in Austria realized for the first time that an infinite growth in road transport solely based on fossil fuels is not possible. As a short-term measure, in the year 1974, the population in Austria was asked not to drive their car for 1 day per week. ${ }^{4}$ In this period Chancellor Kreisky mentioned in his governmental declaration for the first time that it is necessary for an optimal accessibility within Austria to include all means of transport into a national transport strategy (inclusion of road, rail and short distance public transport). It was also for the first time that the government made the suggestion to concentrate the responsibilities for the rail and the road network into one single ministry - as already mentioned above, it took further 30 years until this was realized. In general, the overall strategy was still focused on road construction - as laid out in the "Dringlichkeitsreihung1972 + 1975" (Road Priority ranking Study $1972+1975$ ) [9], which was based on the „Gesamtverkehrskonzept der österreichischen Bundesregierung: September 1968“(Austrian Transport Master Plan 1968) [10]. Also road safety issues became more and more important, and thus funds for road research and road

\footnotetext{
${ }^{4}$ see https://de.wikipedia.org/wiki/\%C3\%96lpreiskrise
}

safety research were explicitly dedicated from 1971 onwards to improve here the knowledge [11].

In the 1980s the improvement of the short-distance public transport system was in the focus to enable rural commuters to reach the workplaces in the urban agglomerations without using their own cars. In the rail system, new shunting yards were planned to improve the freight transport on rail as road freight transit through Austria became a serious problem in terms of congestion and environmental issues (noise and air pollution).

At the end of the 1980s, Chancellor Vranitzky postulated in his government declaration that the objectives of the Austrian transport policy should be a shift of the existing transport demand to that mean of transport which has the best properties regarding traffic safety, economic benefits, environment and efficiency.

Additionally a traffic safety campaign was initiated to reduced traffic fatalities comprising safety education at schools, enforcement of speed and alcohol limits for car drivers, and the installation of the so called "Führerschein auf Probe" - a limited driving license for unexperienced car drivers.

In this period also the catalyst duty for private cars was introduced in Austria in 1987 (first country in Europe) [12]. Further restrictions on road transport to shift freight transport to rail comprised the introduction of restrictive speed limits for noisy heavy good vehicles, the introduction of a night drive prohibition on certain sensible routes, and the increase of capacity of piggyback transport within Austria. Also the inland waterway, the river Danube was mentioned; here existing capacities should be utilized in a more efficient way and the cooperation with other countries (mainly eastern European countries) should be improved.

A similar approach was chosen for the national airline: here relations with other European airlines were introduced to improve the overall service level and supply. In the rail sector, it was suggested to simplify the organization structure towards a more service-orientated company. Until the year 1995, the Austrian railway company should deliver comparable benchmark figures as other efficient rail operators in Europe.

\subsection{Phase 3: 1990 - till today}

In the year 1991, a document describing the Austrian transport policy named "Das Österreichische Gesamtverkehrskonzept 1991 (Austrian Transport Masterplan 1991) [13] was published. In this document the overall objectives of the Austrian transport policy were laid out and a catalogue of measures to reach these goals were listed. To provide an idea, some of the "measures" in the document are listed below:

- Making public transport more attractive

- Promotion of piggyback transport

- Land use measures to reduce the need for travel 
- Set of norms to reduce the road-traffic-related emissions (noise and air pollution)

- Reduction of sulphur and lead content of fuels

- Taxing of "dirty" lorries

- Night drive prohibition for lorries

- Creation of the opportunity to temporarily restrict the road freight transport to ensure certain air quality standards

- And some measures to improve road safety (law to use child car restraint systems for children below 6 years or the control of driving times for professional drivers)

It is worth mentioning here that, in this document, objectives of a transport policy and measures how to achieve these objectives are mixed up. For example, "Making public transport more attractive" is clearly an objective, whereas "night drive prohibition for lorries" is clearly a policy instrument. This mixing up of objectives and policy instruments is a widespread habit in transport planning and complicates seriously the assessment of policy strategies.

To summarize, as mentioned already in the corresponding government declarations, the focus was to make the public transport more attractive, to reduce road-traffic-related emissions (noise and air pollution) and to introduce the concept of true costs in the transport sector. Another activity at this time was to plan to construct about 60.000 park-and-ride places to motivate commuters to switch from private car to public transport.

In this period the negotiation between Austria and the EU took place to become a full member of the EU. A major issue here was the so called "Transitvertrag", a contract which should cap the number of heavy good vehicles passing the Brenner route in Austria. For information - the Brenner route is an environmentally sensible route serving as major corridor between Italy and Germany; the emissions caused by the high number of lorries (e.g. 1,55 million lorries in 2001 and 1,95 million lorries in the year 2013) has been a serious issue. To provide an alternative for the road Brenner route, a discussion for the construction of a Brenner rail tunnel was initiated.

In the year 1996 a new document was published by the Austrian government, which integrated the mode-specific master plans into a common intermodal Austrian Master Plan [14]. In this period investment in transport infrastructure again was seen to reduce the unemployment in Austria. To finance the planned infrastructure projects, it was envisaged to use Private Public Partnership models and to generate financing through road pricing (a flat-rate road pricing (Autobahnvignette) on motorways for private cars was introduced in the year 1997).

In the year 2000 the coalition in Austria changed from a Social Democratic and People's Party coalition to a Peoples Party and Freedom party coalition. In this period a concentration of the agendas of road construction/maintenance and rail network construction/maintenance into a joint ministry called Federal Ministry of Transport, Innovation and Technology
Austria (Bundesministerium für Verkehr, Innovation und Technologie) took place. In the government declaration it was mentioned that the objective of the Austrian transport policy should be the "strengthening of the Austria as a business location". To archive this objective it was recommended to:

- Open the rail market for competition and to ease the access to rail infrastructure for foreign companies

- Creation of a inter-modal transport masterplan

- Expansion of the rail and road network, plus improvement of the inland waterways as an environmentally friendly mean of freight transport

- Optimization of public transport

- Mode shift of new freight transport demand towards environmentally friendly means of transport

- Gap closure in the high level road network

- Introduction of a distance based heavy good vehicle road pricing system (Start date 1. January 2004)

- Reorganization of the Austrian railway operator (separation between infrastructure and operation)

- Ownership transfer of trunk roads from national state to the federal states (in the year 2002)

In the year 2007 again there was a change in government coalition from the former People's Party / Freedom Party coalition to a Social Democratic / People's Party coalition. This coalition is in place until today. The general orientation in the Austrian transport policy did not change; still the stimulation of the Austrian economic growth through improvements in transport infrastructure is the main focus.

Figure 9 summarises the historical development described before using a time line. In the red rectangles one can see important events happening on an European scale, such as WWI and WWII, the signature of the Austrian Treaty after WWII (year 1955), the 1st Oil Crisis (year 1974), the 2nd Oil Crisis (year 1980), the fall of the Iron Curtain (year 1989), the Maastricht Treaty (year 1993), Austria joining the EU (year 1995), European Transport Policy for 2010: Time to decide (2001), White Paper on Transport (year 2011).

In blue rectangles one can see the publications dates of the "official" published documents dealing with the Austrian transport policy, such as the "Gesamtverkehrskonzept der österreichischen Bundesregierung : September 1968" (Austrian Transport Masterplan 1968) (year 1968), the "Dringlichkeitsreihung1972 + 1975" (Road Priority Ranking study 1972 + 1975) (year 1978), the "Dringlichkeitsreihung 1980" (Road Priority Ranking study 1980) (year 1980), the foundation of the ASFINAG - Austrian motorway financing corporation in year 1982, the "Das Österreichische Gesamtverkehrskonzept 1991" (Austrian Transport Master Plan 1991) (year 1991), the "Der österreichische Bundesverkehrswegeplan" (Federal Transport Infrastructure 
Fig. 9 Development of population, number of cars (absolute), GDP per capita (in 1990 International Geary-Khamis dollars), energy consumption for transport - relative $(1950=1)$ and major events (EU and Austria) for the period 1900 till 2015

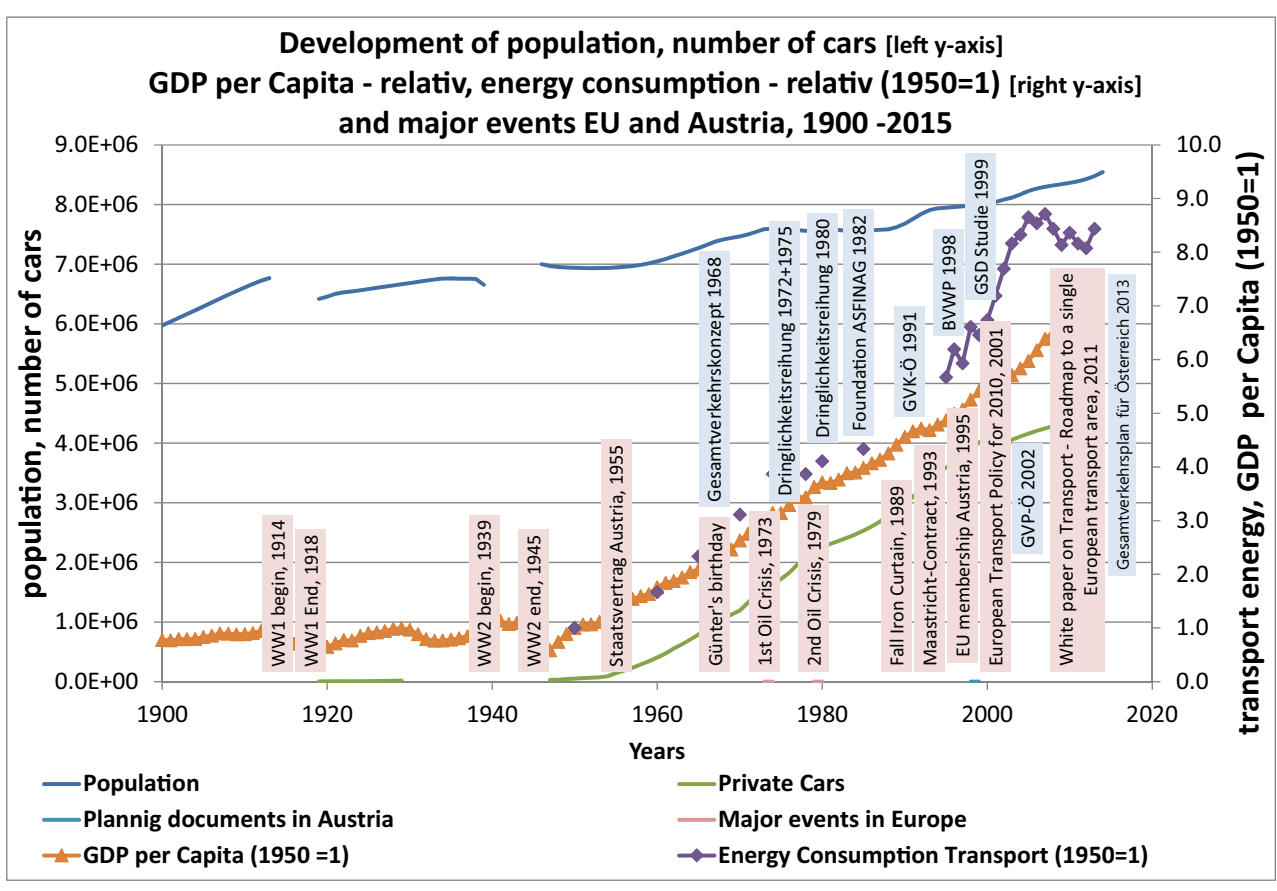

Plan 1998) (year 1998), the "GSD Studie" (Design Study of Road Transport Network in the Danube Region - Study) (year 1999), the "GVP-Ö" (Austrian Transport Master Plan 2002) (year 2002) and the "Gesamtverkehrsplan für Österreich" (Austrian Transport Master Plan 2013) (year 2013).

Figure 9 relates all these documents and events to the population and car number development (on the left side Y-axis) and to the relative development of the consumed transport energy and the GDP per head development (on the right side Y-axis) for the period 1900 to 2015.

\subsection{Analysis of "official" documents in Austria regarding transport policy}

In this section an overview of the published documents regarding transport policy is given. Column 1 of Table 1 shows the year of publication. In column 2 the official abbreviation of the document is shown, then the full name in German and the responsible author(s) are listed. In the column headed "Objectives" the main objectives, listed within the specific document regarding transport policy are shown. In the column headed "Targets" the target (-indicators) are listed, in the case no target (-indicators) could be found in the document a comment by the author of this paper is shown. In the last column headed "Comments by the author", remarks concerning the document are provided. In total eight documents were published in Austria dealing with national transport policy in the period between 1968 and today.

The documents listed in Table 1 mainly have the objective to give advice which infrastructure projects should be realized and in which order. Especially the earlier documents focused on the order of implementation under the constraints of financing, construction capacity and employment aspects. The transport policy in Austria in the period 1950-1970 and 1970-1990 can be classified as solely "demand orientated". Under the term "demand orientated" provision of infrastructure one can understand that the infrastructure was built because the demand, mainly the demand for car mobility, should be satisfied. No transport demand management measures to reduce/steer the demand for car mobility were taken into consideration or included in the national Austrian transport policy in these periods.

In the document GVK-Ö 1991 for the first time the objective "Avoidance of unnecessary traffic" was mentioned. Unfortunately no monitor-able target (-indicators) were defined in this document, so it was not possible to assess the implemented strategies against these indicators.

As it can be seen, this was only a very short period. In the following published documents the economic point of view in transport policy making became again the dominating objective, which can be clearly seen when looking at the objectives of the BVWP (year 1998), the objectives of the GSD-Study (year 1999) and the GVP-Ö (year 2002), where the main objectives were the "Strengthening of Austria as a business location". The paradigm "Avoidance of unnecessary traffic" completely disappeared from the agenda in the period between 1998 and 2013.

The last published document, the Gesamtverkehrsplan für Österreich (year 2013), again is now a modern, comprehensive TMP, where infrastructure improvements and also transport demand management measures are included and also monitor-able target (-indicators) are provided. This will enable to assess the objective-fulfillment in a later stage. We will 
Table 1 Overview of transport policy related documents in Austria

\begin{tabular}{|c|c|c|c|c|}
\hline Year & $\begin{array}{l}\text { 1. Abbreviation } \\
\text { 2. Title German } \\
\text { 3. Title - translation to } \\
\text { English (by the Author) } \\
\text { 4. Reference }\end{array}$ & Objectives & Targets & Comments by the author \\
\hline 1968 & $\begin{array}{l}\text { 1. n.a. } \\
\text { 2. Gesamtverkehrskonzept } \\
\text { der österreichischen } \\
\text { Bundesregierung: } \\
\text { September 1968 } \\
\text { 3. Transport Master Plan of } \\
\text { the Austrian Government } \\
\text { 1968 } \\
\text { 4. [10] }\end{array}$ & n.a. & n.a. & $\begin{array}{l}\text { Unfortunately it was not possible to get a } \\
\text { copy of this document. }\end{array}$ \\
\hline 1977 & $\begin{array}{l}\text { 1. n.a. } \\
\text { 2. Dringlichkeitsreihung } \\
1972+1975 \\
\text { 3. Road Priority Ranking } \\
\text { Study } 1972+1975 \\
\text { 4. [9] }\end{array}$ & $\begin{array}{l}\text { Development of an objective, scientific } \\
\text { method to rank road infrastructure } \\
\text { projects }\end{array}$ & $\begin{array}{l}\text { Priority list of road construction } \\
\text { projects (motorways and trunk } \\
\text { roads) for all projects in Austria }\end{array}$ & $\begin{array}{l}\text { Sectoral study, only road infrastructure } \\
\text { project under investigation. } \\
\text { Criteria are based on effectiveness of } \\
\text { construction cost, safety and traffic } \\
\text { amount. } \\
\text { Scientific methodology, ranking biased } \\
\text { by political influence }\end{array}$ \\
\hline 1980 & $\begin{array}{l}\text { 1. n.a. } \\
\text { 2. Dringlichkeitsreihung } \\
1980 \\
\text { 3. Road Priority Ranking } \\
\text { Study } 1980 \\
\text { 4. [15] }\end{array}$ & $\begin{array}{l}\text { Improvement of the scientific method } \\
\text { applied in the year } 1972 \text { and } 1975 \text { through } \\
\text { including of more detailed indicators } \\
\text { (congestion, time savings, energy savings, } \\
\text { road safety, environmental impact, } \\
\text { accessibility, cost efficient) and the } \\
\text { application of a 4-stage transport model } \\
\text { for Austria to estimate the transport de- } \\
\text { mand }\end{array}$ & $\begin{array}{l}\text { Priority list of road construction } \\
\text { projects (motorway and trunk } \\
\text { roads) for the next } 10 \text { year } \\
\text { period }\end{array}$ & $\begin{array}{l}\text { Sectoral study, only road infrastructure } \\
\text { projects under investigation. } \\
\text { Criteria are more detailed than before, } \\
\text { but ranking is still biased by political } \\
\text { influence }\end{array}$ \\
\hline 1991 & $\begin{array}{l}\text { 1. GVK-Ö } 1991 \\
\text { 2. Das Österreichische } \\
\text { Gesamtverkehrskonzept } \\
\text { 1991 } \\
\text { 3. Transport Master Plan } \\
\text { 1991 } \\
\text { 4. [13] }\end{array}$ & $\begin{array}{l}\text { 1. Avoidance of unnecessary traffic } \\
\text { 2. Promotion of environmentally friendly } \\
\text { means of transport and redistribution } \\
\text { towards non-motorized means of trans- } \\
\text { port } \\
\text { 3. Use of newest technological standards } \\
\text { 4. Public participation } \\
\text { 5. Introduction of true cost pricing in the } \\
\text { transport sector } \\
\text { 6. Cooperation between different means of } \\
\text { transport }\end{array}$ & $\begin{array}{l}\text { No monitor-able targets regarding } \\
\text { transport related indicators were } \\
\text { provided }\end{array}$ & $\begin{array}{l}\text { For the first time in Austria this was } \\
\text { overarching transport master plan } \\
\text { including all means of transport } \\
\text { No monitor-able indicators were defined } \\
\text { No monitoring process was installed }\end{array}$ \\
\hline 1998 & $\begin{array}{l}\text { 1. BVWP } \\
\text { 2. Der österreichische } \\
\text { Bundesverkehrswegepl- } \\
\text { an } \\
\text { 3. Austrian Federal } \\
\text { Transport Infrastructure } \\
\text { Plan } \\
\text { 4. [14] }\end{array}$ & $\begin{array}{l}\text { This document describes the process to } \\
\text { determine which infrastructure projects } \\
\text { have to be realized to fulfil the objectives } \\
\text { described in the GVK-Ö-1991. } \\
\text { It summarizes the comprehensive scientific } \\
\text { studies carried out in different work } \\
\text { packages, such as project management, } \\
\text { analysis, prognosis, suggestion for a } \\
\text { multimodal transort infrastructure }\end{array}$ & $\begin{array}{l}\text { No monitor-able targets regarding } \\
\text { transport related indicators were } \\
\text { provided }\end{array}$ & $\begin{array}{l}\text { The document provided a list of } \\
\text { infrastructure projects which should } \\
\text { be realized in the coming decades to } \\
\text { meet the future demand. } \\
\text { No transport system related } \\
\text { targets/indicators or a monitoring } \\
\text { process to monitor them was sug- } \\
\text { gested. }\end{array}$ \\
\hline
\end{tabular}
network, and assessment. Output of the project was a detailed list of infrastructure projects for rail and road with a total sum of 21.8 billion Euro for the rail and 2.9 billion Euro in the road sector.

1999 1. GSD Studie

2. Gestaltung des Straßennetzes im Donaueuropäischen Raum (GSD - Studie)

3. Design Study of Road Transport Network in the Danube Region - Study

4. [16]

Only road network is taken into consideration!

1. Economic and social development by saving space and environment

2. Ensuring the living and settlement space

3. Offensive conservation of economic development through improvement of innovation-, adaption-, and competitiveness-abilities

4. Road network design in accordance with the principles of environmental, social and
No monitor-able targets were defined.
The GSD-study is a priority list for road construction projects. The methodology for the ranking is not made explicit, and a strong political bias is identifiable. 
Table 1 (continued)

\begin{tabular}{|c|c|c|c|c|}
\hline Year & $\begin{array}{l}\text { 1. Abbreviation } \\
\text { 2. Title German } \\
\text { 3. Title - translation to } \\
\text { English (by the Author) } \\
\text { 4. Reference }\end{array}$ & Objectives & Targets & Comments by the author \\
\hline 2013 & $\begin{array}{l}\text { 1. GVP-Ö } \\
\text { 2. Generalverkehrsplan } \\
\text { Österreich } 2002 \text { - } \\
\text { verkehrspolitische } \\
\text { Grundsätze und } \\
\text { Infrastrukturprogramm } \\
\text { 3. Transport Master Plan } \\
2002 \\
\text { 4.[17] } \\
\text { 1. n.a. } \\
\text { 2. Gesamtverkehrsplan für } \\
\text { Österreich } \\
\text { 3. Transport Master Plan } \\
\text { Austria 2013 } \\
\text { 4. [18] }\end{array}$ & $\begin{array}{l}\text { economic orientated transport policy } \\
\text { under consideration of all means of } \\
\text { transport } \\
\text { Sustainable Mobility } \\
\text { 1. Strengthening of Austria as a business } \\
\text { location } \\
\text { 2. efficient and demand-orientated extension } \\
\text { of transport networks } \\
\text { 3. improvement of transport safety } \\
\text { 4. secure financing of infrastructure projects } \\
\text { 5. to make implantation easier and faster }\end{array}$ & $\begin{array}{l}\text { Ad 1) social } \\
\text { - } 2015 \text { - all major train stations } \\
\text { (140) barrier free } \\
\text { - Bonus malus system for } \\
\text { punctuality, cleanliness, and } \\
\text { other quality factors, ticket } \\
\text { prices close to inflation } \\
\text { Ad 2) Safety } \\
\text { - }-50 \% \text { of fatalities till } 2020 \\
\text { - } 20 \% \text { of accidents with injured } \\
\text { people } \\
\text { Ad 3) Environment } \\
\cdot \mathrm{CO}_{2} \rightarrow-19 \% \text { till } 2025 \text { (base year } \\
2010) \\
\text { - PM } \\
\text { - NOx } \rightarrow-50 \% \text { till } 2025 \\
\text { Ad } 4 \text { ) Efficiency } \\
\cdot \text { Reduction of energy } \\
\text { consumption from } 240 \\
\text { Petajoule to } 210 \text { Petajoule in } \\
2025 \text { (-13\%) } \\
\text { - Significant reductions of travel } \\
\text { time for rail (west } 30 \text { min, south } \\
90 \text { min) }\end{array}$ & $\begin{array}{l}\text { In the document for the first time the } \\
\text { topic "monitoring" is addressed. By } \\
\text { reading through the corresponding } \\
\text { chapter it was learned that monitoring } \\
\text { comprises only the monitoring } \\
\text { whether the suggested infrastructure } \\
\text { projects are realized or not. } \\
\text { No monitoring if the intended objectives } \\
\text { of the transport strategy could be met } \\
\text { or not are foreseen. } \\
\text { In this document for the first time } \\
\text { monitor able- target values are ex- } \\
\text { plicitly listed. } \\
\text { Although this is a step in the right } \\
\text { direction when assessing the } \\
\text { document against the Ideal Decision } \\
\text { Making Process (detailed in } \\
\text { section 4), no mitigation policies are } \\
\text { mentioned in the case the suggested } \\
\text { target values could not be achieved. }\end{array}$ \\
\hline
\end{tabular}

see what the Austrian government will achieve with this new attempt to solve the Austrian transport challenges.

\section{The "Ideal Decision Making Process" (IDMP)}

Within the EU-funded project PROSPECTS - Procedures for Recommending Optimal Sustainable Planning of European City Transport Systems [19] -, the decision-making processes for urban transport planning were under investigation, and an "ideal" decision-making process for sustainable transport planning in the European context was identified. This process, which incorporated results from a number of previous EU research projects, was described in detail in a "Decision Makers Guidebook" (DMG) ([20, 21]. The DMG was designed to help those involved in decisions on land use and transport, in cities throughout Europe, whether as politicians, professional advisers, stakeholders or individual citizens.

This ideal decision making process cannot only be used to assess a urban planning processes; in the opinion of the author it can also applied in a national context, which will be shown later in this section. Before that, the general structure of the "Ideal Decision Making Process" will be introduced with Fig. 10:

The suggested IDMP contains the following initial steps: (1) a clear definition of objectives and indicators; (2) the explicit definition of problems, at present and in the future; and (3) a specification of possible future scenarios. Subsequent steps involve: (4) the identification of possible instruments to tackle the problems; (5) the assessment of those barriers to implementation which will arise for certain policy instruments; and (6) the development of strategies as packages of instruments that can to reduce the impact of the barriers. 


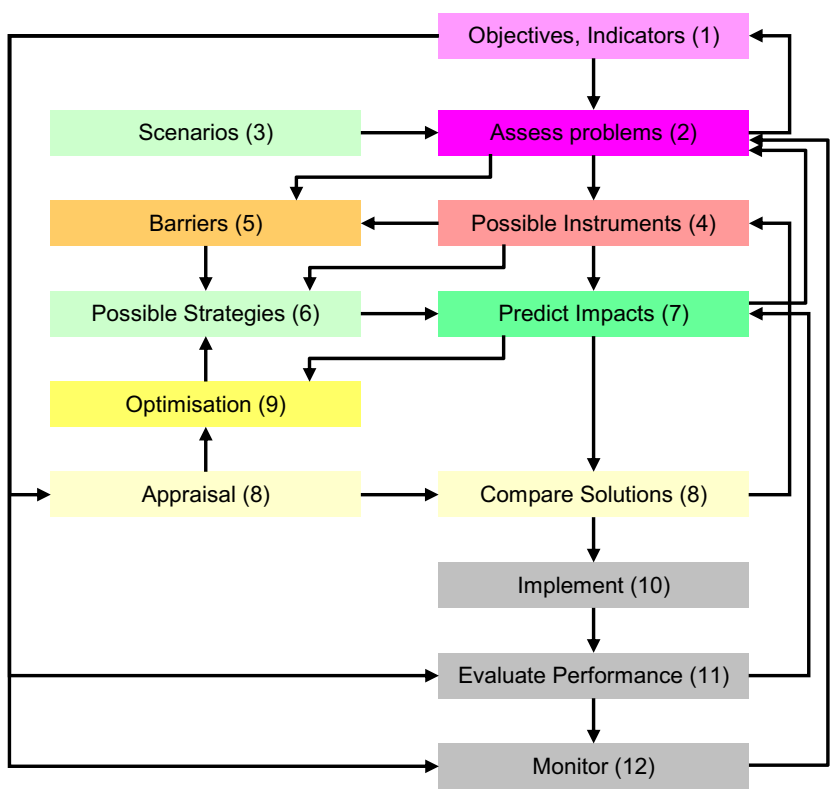

Fig. 10 The "Ideal Decision Making Process" (IDMP) introduced in the Decision Makers' Guidebook

The next steps are concerned with assessment and involve: (7) the use of models to make quantified predictions of the impacts of individual instruments and/or strategies; and (8) a comparison of these predictions, using an appraisal method which is consistent with the previously specified objectives. These steps may well identify ways in which the instruments or strategies can be improved, and it is possible at this stage to (9) use optimization techniques to help identify such improvements.

The final steps in the process take places once a decision has been taken with respect to a particular instrument or strategy: (10) the instrument/strategy is implemented; (11) its performance is assessed against the original objectives (with such assessment potentially helping to improve the predictive process); and (12) the ongoing regular monitoring of the instrument/strategy.

Exemplarily three elements out of the twelve above mentioned elements of the IDMP will be discussed in more detail here in this document. More information regarding the "Ideal Decision Making Process" and its application can be found in [22-24].

\subsection{Objectives (1)}

Objectives are broad statements of the improvements which a country is seeking in its land use and transport system. It is important that decision-makers and other stakeholders determine (preferably through public participation process) the objectives which they wish to pursue.

Relating to sustainability, seven objectives are suggested in the DMG, including protection of the environment, liveable streets and neighbourhoods, safety, equity and social inclusion, economic efficiency, contribution to economic growth, and intergenerational equity. Usually it is not possible to satisfy all of the objectives which may be desirable, as some of them will conflict; for example it is often difficult to improve economic growth without intruding into the environment. Therefore, priorities among objectives are important.

Still some European countries (UK [25], Germany [26], France [27], Austria) focus mainly on economic efficiency and growth, with much less concern for environment and equity. This leads to strategies which prioritise policy instruments relating to road infrastructure provision. It follows that if objectives are set inappropriately (they are unbalanced), a designed strategy cannot achieve sustainability.

Objectives relating to intergenerational equity, social inclusion and intergenerational equity are presently given the lowest priority in both Europe and elsewhere [24, p. 48]. It follows that non-motorized transport (which is particularly associated with the poor, and which creates no pollution and has no need of fuel energy) is considered as unimportant by transport planners and decision makers, as well as by those members of the public who are in a position to influence policy-making.

\subsection{Policy instruments (4)}

Policy instruments are the tools which can be used to overcome problems and achieve objectives. There are a number of instruments, which can be categorized by type of intervention: land use measures; infrastructure provision; management of the infrastructure; information provision; attitudinal and behavioral measures; and pricing.

Policy instruments that attempt to change travel behavior (e.g. pricing, TDM (travel demand management) and attitudinal and behavioral measures) are rarely used.

\subsection{Strategies (6)}

There is no single solution to national, regional or urban transport problems. Thus, there is a need to develop a transport and land use strategy that consists of a combination of policy instruments. Such a strategy is very likely to be more effective than applying only a single instrument. In this way synergy can be achieved.

For more information on the other elements of the "Ideal Decision Making Process" please see the Decision Makers Guidebook [24] which is downloadable for free. ${ }^{5}$

\footnotetext{
${ }^{5}$ http://www.ivv.tuwien.ac.at/uploads/media/DMG_English_ Version_2005_02.pdf.
} 


\section{Assessment of the austrian TMP activities against the "ideal decision making process"}

In this section an attempt is made to check which elements of the IDMP were included in the Austrian TMP activities. Table 2 provides therefor a concise overview of the findings:

The first 2 columns of Table 2 show again the publication year and the name of the corresponding documents. Column 3 gives an indication whether the study scope was mono- or multi-modal orientated. Columns 4 to 14 show if the corresponding TMP-study has included the corresponding IDMPactivities. A "+"-sign indicates that this activity was included in the TMP-document, a "-"-sign indicates that this activity was not included.

It can be seen that over time, the TMP documents became more comprehensive and more and more elements of the IDMP were included.

They improved from a mono-modal point of view towards a multi-modal point of view. In a next step the identification of problems and scenarios was added to the TMPs, but still no transport demand management instruments were taken into consideration explicitly. A major step forward from the point of methodology, was the 2013 published "Gesamtverkehrsplan für Österreich 2013", which included nearly all elements suggested by the IDMP. Only the monitoring process and the feedback to the "assess problems"-activity was not explicitly addressed in this document and should be integrated in future TMPs.

Summarizing, the framework of the IDMP is a useful tool to assess the quality of national and regional TPMs. The application of the IDMP shows the deficits in these documents and shows that only if all parts of the IDMP (elements 1 to 12) are installed in a specific country/region a serious assessment of the transport policies/strategies implemented can be carried out. Especially the definition of target indicators and the installation of related mid/long term monitoring processes are a precondition for an assessment. It seems that responsible politicians/institutions are aware of this issue, but are not very keen to install these processes, because then their failure in achieving the proposed results can be seen explicitly.

\section{Conclusions}

In this paper the overall development of some key indicators which describe Austria's development regarding the transport sector is given and time series from 1900 till today for a set of indicators are provided. In parallel to this, the government constellations in Austria were listed and the corresponding government declarations were shown and summarized. By analysing the government declarations three distinct phases in the Austrian transport policy could be identified:
Phase 1, Between1950 and 1970, put a clear focus on reconstruction after WWII and a clear focus on road construction and employment aspects.

Phase 2, Between 1970 and 1990, was influenced by the Oil Crises and following that, an integration took place from a mono-modal point of view towards a multimodal view including some first attempts to integrate environmental issues, too. Still, these two phases were dominated by the concept of demand orientated infrastructure provision.

Phase 3, Comprising the period from 1990 onwards until today, can be characterized that at the beginning environmental issues became more important key phrase "Avoidance of unnecessary traffic", but this was only a very short episode in the Austrian transport policy. Very soon the main objective of the Austrian transport policy was again dominated by an economic point view - key phrase "Strengthening of Austria as a business location".

The activities documented in "Gesamtverkehrsplan für Österreich 2013" show a shift towards a more scientific based approach to solve the transport related challenges - but it is too early to assess the outcome of this process at present.

The application of IDMP framework derived in the PROSPECTS project [19] on the Austrian TMPs showed clearly the improvement in the quality and comprehensiveness of the TMP documents over time. While TMPs from the 1960ies till the 1980ies were solely mono-modal younger documents addressed all means of transport. Further it could be shown that younger documents became more sophisticated because they comprise additionally the identification of transport related environmental challenges, they include potential future scenarios and there are listed potential instruments/ policy packages to mitigate the negative impacts of transport.

Similar research should be carried out for other countries/ regions of the world, too, to identify the current state of the transport planning practice in these countries regarding the IDMP-framework and to help to improve their TMPs towards completeness.

This contribution here is a first attempt to carry out a structured analysis of the transport policy activities in Austria. It turned out that long term data series are very difficult to obtain and that it is difficult to identify the impacts of the past TMPs and assess their outcome against reality. One problem identified is that TMPs the most of the time do not include dedicated numeric values for target indicators. For example there exist no definitive values for modal split shares or $\mathrm{CO}_{2}$-emissions in the existing TMP documents, therefore an assessment against these target values is not possible, yet. 


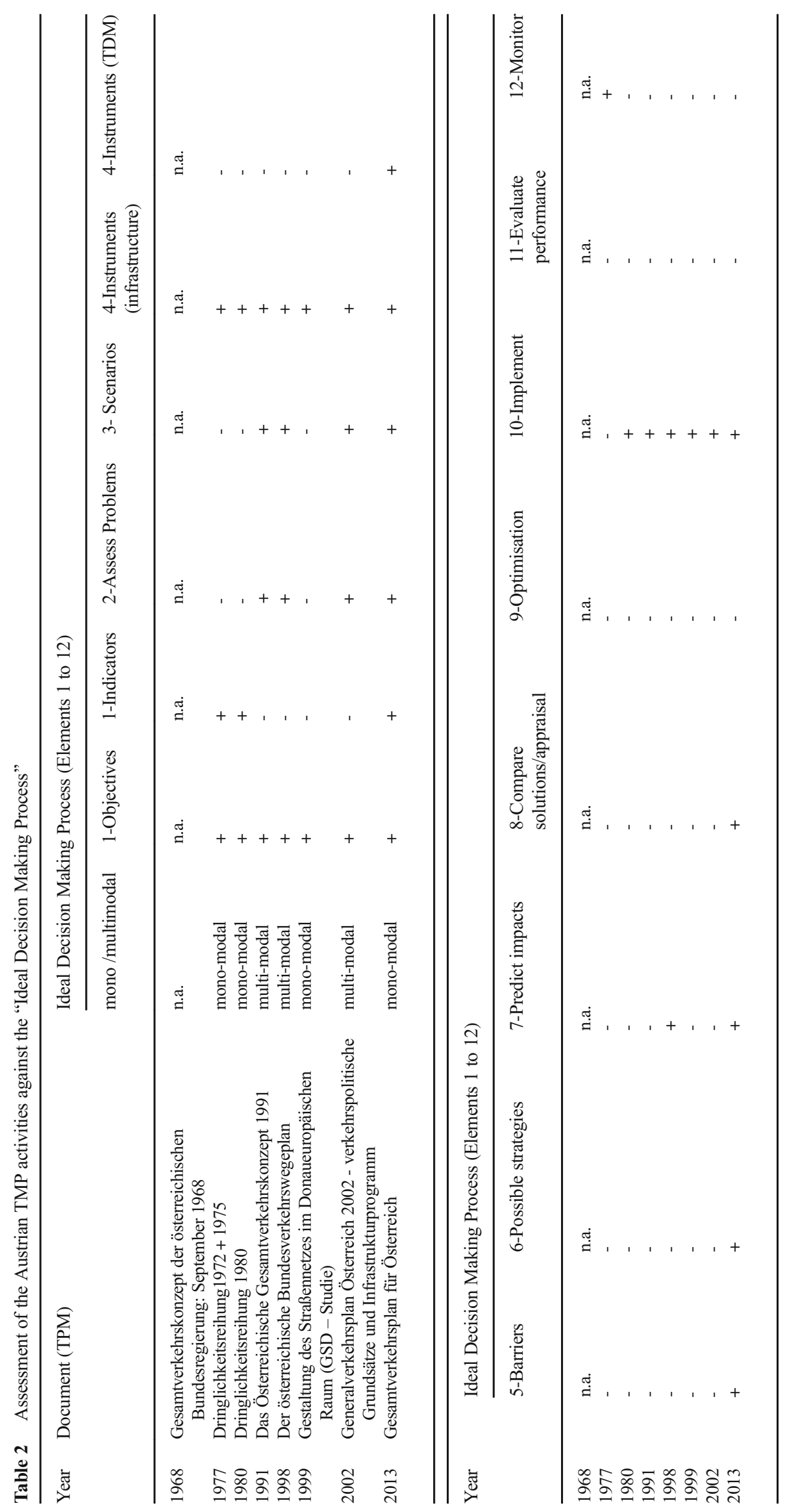


Further adequate monitoring systems are still not fully implemented on a regular basis, for example, household surveys, which are necessary to derive modal split figures were only carried out in the year 1995 and 2015 (data from this survey are not available yet) in Austria.

Therefore monitoring systems, such as constantly recurring household surveys should be carried out at least every 10 years, or even better every 5 years, to provide the necessary information how the in the TMPs suggested and implemented policy strategies perform against a specific set of target indicators as for example modal split, number of trips per day per person, travel time budget, energy consumption for mobility, etc. These monitoring processes should be harmonized within all EU-countries and have to be installed EU wide to enable cross comparisons of the transport systems between all EU countries to check whether the overall transport system is developing towards sustainability.

Acknowledgements I would like to express my thanks to the unknown reviewers of the manuscript for their useful comments to improve the quality of the paper and my colleagues here at the Institute for Transportation, University of Technology Vienna, for their support during the paper writing process, for their useful hints where to find time series data and for their comments on the paper. The author acknowledge the TU Wien University Library for financial support through its Open Access Funding Program.

Open Access This article is distributed under the terms of the Creative Commons Attribution 4.0 International License (http:// creativecommons.org/licenses/by/4.0/), which permits unrestricted use, distribution, and reproduction in any medium, provided you give appropriate credit to the original author(s) and the source, provide a link to the Creative Commons license, and indicate if changes were made.

\section{References}

1. Grübler A (1988) The rise and fall of infrastructures.

2. BMVIT (2004) Statistik Straße \& Verkehr.

3. Emberger G (ed) (2005) Freight transport - a holistic approach. Beiträge zu einer ökologisch und sozial verträglichen verkehrsplanung. Insitut für Verkehrsplanung und Verkehrstechnik - Technische Universiät Wien, Wien

4. Marchetti C (1993) On Mobility.

5. Emberger G (ed) (2005) Freight transport - a holistic approach. Inst. für Verkehrsplanung u. Verkehrstechnik d. Techn. Univ. Wien, Wien

6. ÖBB (2013) Geschäftsbericht 2013 - Wir bewegen Österreich.

7. ASFINAG (2012) Das Autobahnetz in Österreich - 30 Jahre ASFINAG.
8. Steininger G (2008) Ziele und Vorgaben der österreichischen Verkehrspolitik in den Koalitionsabkommen der Bundesregierung - ein Zeitvergleich 1945-2007. Schriftenreihe des Instituts für Transportwirtschaft und Logistik - Verkehr, 02/2008 Institut für Transportwirtschaft und Logistik, WU Vienna University of Economics and Business, Vienna

9. Wottawa H, Knoflacher H (1977) Dringlichkeitsreihung $1972+$ 1975 - Zusammenführung der Einzelkriterien.

10. Bundesministerium für Verkehr und verstaatlichte Unternehmungen (1968) Gesamtverkehrskonzept der österreichischen Bundesregierung: September 1968

11. BGBL. Nr. 286/1971 vom 5. August 1971 (BG vom 16. Juli 1971) (Bundesstraßengesetz 1971 -BStG 1971).

12. BGBl. Nr 395/1985.

13. Bundesminsterium für öffentliche Wirtschaft und Verkehr (1991) Das österreichische Gesamtverkehrskonzept 1991 (GVK-Ö 1991).

14. Kovacic W (1999) Der österreichische Bundesverkehrswegeplan Abgeschlossene und laufende Arbeitspakete.

15. Schussek K (1980) Dringlichkeitsreihung 1980

16. Hamza C, Palme G, Puchinger K, Sedlmayer H, Snizek S (1999) Gestaltung des Straßennetzes im Donaueuropäischen Raum (GSD - Studie)

17. BMVIT (2002) Generalverkehrsplan Österreich 2002 (GVP-Ö 2002) verkehrspolitische Grundsätze und Infrastrukturprogramm; Bericht Januar 2002. Bmvit, [Wien]

18. BMVIT (2013) Gesamtverkehrsplan für Österreich

19. PROSPECTS (2000-2003) PROSPECTS - Procedures for Recommending Optimal Sustainable Planning of European City $\mathrm{Tr}$ a n s por t $\mathrm{S}$ y s t e m s. ht t p:// w w w. ivvtuwienacat/forschung/projekte/international-projects/prospects2000.html

20. May AD, Karlstrom A, Marler N, Matthews B, Minken H, Monzon A, Page M, Pfaffenbichler PC, Shepherd S (2003) Decision Maker's Guidebook

21. May AD, Karlstrom A, Marler N, Matthews B, Minken H, Monzon A, Page M, Pfaffenbichler PC, Shepherd S (2005) Decision Maker's Guidebook

22. Emberger G, Pfaffenbichler PC, Jaensirisak S, Timms P (2008) Ideal' decision-making processes for transport planning: a comparison between europe and south east asia. Transp Policy 15(6):341349

23. May AD, Shepherd SP, Emberger G, Ash A, Zhang X, Paulley N (2005) Optimal land use transport strategies: Methodology and Application to European cities. 84th TRB annual meeting, reviewed

24. May AD, Karlstrom A, Marler N, Matthews B, Minken H, Monzon A, Page M, Pfaffenbichler P, S. S (2005) Developing Sustainable Urban Land Use and Transport Strategies - A Decision Makers' Guidebook. 2nd revised Edition edn. Institute for Transport Studies, University of Leeds, Leeds

25. (DfT) DfT (2016) Corporate report - Single departmental plan 2015 to 2020

26. Randelhoff M (2013) Die verkehrspolitischen Ziele von CDU/CSU

27. SNIT (2011) National Transport Infrastructure Strategy for France 